\title{
Penanggulangan Tindak Pidana Oleh Bea Dan Cukai Jakarta Terhadap Penyelundupan Smartphone
}

\author{
Menra Lianjaya Putra, Trisno Raharjo, Yeni Widowaty \\ Fakultas Hukum, Universitas Muhammadiyah Yogyakarta \\ Korespondensi : menra.lianjaya.2013@law.umy.ac.id
}

\section{Info Artikel \\ Riwayat: \\ Diajukan : 22 Februari 2021 \\ Ditelaah : :21 Maret 2021 \\ Direvisi : 21 Maret 2021 \\ Diterima : 23 Maret 2021}

Kata Kunci :

penanggulangan;

penyelundupan; smartphone

ilegal, direktorat jenderal bea

dan cukai

DOI:

10.18196/ijclc.v2i1.11565

\section{Pendahuluan}

\begin{abstract}
Abstrak
Penyelundupan smartphone banyak terjadi di Indonesia, salah satunya yang terjadi di Bea Cukai Jakarta. Tingginya permintaan terhadap smartphone sekalipun harganya mahal, dimanfaatkan oleh oknum untuk menyediakan smartphone dengan varian yang beragam dan harga murah melalui jalan yang ilegal dengan penyelundupan. Luasnya daerah kepabeanan Indonesia menjadikan pengawasan yang dilakukan belum maksimal sehingga masih banyak barang yang dapat keluar masuk secara ilegal tanpa membayar bea cukai. Penelitian ini akan membahas lebih lanjut tentang bagaimana upaya penanggulangan yang dapat dilakukan oleh Bea dan Cukai Jakarta terhadap penyelundupan smartphone ilegal. Penelitian dilakukan secara yuridis empiris dengan menggunakan pendekatan undang-undang, pendekatan kasus, dan pendekatan historis. Data yang digunakan adalah data primer yang berasal dari fakta di lapangan yang diperoleh dengan cara wawancara dengan narasumber. Kemudian data sekunder yang diperoleh dari aturan perundang-undangan dan studi keperpustaan meliputi bahan hukum primer, bahan hukum sekunder dan bahan hukum tersier. Hasil penelitian menunjukkan bahwa upaya penanggulangan penyelundupan smartphone oleh Bea dan Cukai Jakarta, didasarkan pada ketentuan prosedur pelaksanaan penegakan hukum sudah sesuai dengan Peraturan Direktorat Jenderal Bea Dan Cukai Nomor P-53/Bc/2010 Tentang Tatalaksana Pengawasan Direktorat Jenderal Bea dan Cukai yang meliputi : Intelejen, Penyidik, Penindak, dan Sarana Operasi. Adapun faktor-faktor yang menyebabkan maraknya terjadi penyelundupan smartphone ilegal, seperti faktor geografis, faktor penegak hukum dan faktor ekonomi.
\end{abstract}

Teknologi merupakan sarana untuk menyediakan kebutuhan yang diperlukan bagi kelangsungan dan kenyamanan hidup manusia. Teknologi dapat memberikan bantuan dan telah menjadi bagian penting dari kehidupan masyarakat. Hadirnya teknologi membuat manusia mudah melakukan segala hal. Bahkan teknologi sudah menjadi kebutuhan pokok yang harus di miliki manusia. Perkembangan teknologi juga mempengaruhi gaya berkomunikasi dan menunjukkan bahwa masyarakat lebih cenderung bergantung pada teknologi.

Smartphone merupakan salah satu teknologi canggih yang berkembang didunia modern. Teknologi ini hampir dimiliki setiap manusia di dunia. Kemampuan smartphone layaknya komputer yang di dukung oleh sebuah sistem operasi canggih. Keberadaan smartphone sebagai perangkat gerak (mobile) memungkinkan pengguna untuk dapat menggunakan fasilitas telepon maupun mengakses internet secara bersamaan. ${ }^{1}$ Tidak mengherankan jika kebutuhan akan smartphone sangat tinggi dan hampir semua

\footnotetext{
${ }^{1}$ Rotasi. (2013). Ponsel Pintar Gaya Hidup, di akses pada tanggal 21 April 2018 http://rotasinews.com/ponselpintar-jadi-gaya-hidup/
} 
orang memiliki smartphone. Tingginya permintaan terhadap smartphone dimanfaatkan oleh oknum untuk menyediakan smartphone dengan varian yang beragam dan harga murah. Sayangnya, masih banyak penjual nakal yang berusaha mengakali harga smartphone dengan menjual secara murah, meski dilakukan secara ilegal sekalipun.

Pihak Asosiasi Pengusaha Ponsel Indonesia menyebutkan merk Iphone dan Xiaomi merupakan smartphone yang paling banyak di perjual belikan secara ilegal. Dari 2 (dua) smartphone didapatkan 20.545 ponsel ilegal hasil penindakan Direktorat Jenderal Bea dan Cukai (DJBC) Kementerian Keuangan. Kebanyakan IPhone dan xiaomi ilegal yang beredar di Indonesia bisa masuk melalui jalur-jalur yang tidak resmi dan tidak bayar pajak. Banyaknya peminat smartphone impor tersebut karena kebutuhan akan fitur yang canggih, adu gengsi, dan mengikuti perkembangan teknologi didalam dunia komunikasi.

Kegiatan impor smartphone di Indonesia, tidak hanya melalui jalur laut saja tetapi kegiatan impor tersebut dapat juga melalui jalur darat maupun udara. Kegiatan masuknya barang impor dan ekspor dalam kawasan kepabean Indonesia sudah di atur Undang-Undang Republik Indonesia Nomor 17 Tahun 2006 Tentang Perubahan Atas Undang-Undang Nomor 10 Tahun 1995 Tentang Kepabeanan. Pengawasan barang yang akan di ekspor maupun di impor di atur oleh Undang-undang Kepabeanan dibawah Menteri Keuangan yaitu Dirjen Bea Cukai sebagai pengawas. Sehingga peranan Dirjen Bea Cukai dalam melaksanakan tugas pokok Kementerian Keuangan di bidang kepabeanan dan cukai, berdasarkan kebijaksanaan yang ditetapkan oleh Menteri dan mengamankan kebijaksanaan pemerintah yang berkaitan dengan lalu lintas barang yang masuk atau keluar daerah kepabeanan dan pemungutan bea masuk dan cukai serta pungutan negara lainnya berdasarkan peraturan perundang-undangan yang berlaku. $^{2}$

Penyelundupan merupakan jenis tindak pidana yang dilakukan oleh seseorang atau sekelompok orang dengan cara memasukkan (impor) atau mengeluarkan (ekspor) barang dengan tidak memenuhi ketentuan peraturan perundang-undangan yang berlaku, melanggar hukum dan merugikan negara. ${ }^{3}$ Penyelundupan mempunyai pengaruh terhadap segi-segi kehidupan masyarakat baik terhadap segi kehidupan sosial, ekonomi, politik maupun kebudayaan. ${ }^{4}$ Penyelundupan berasal dari kata selundup. Menurut Kamus Besar Bahasa Indonesia kata selundup diartikan menyelunduk, menyuruk, masuk dengan sembunyi-sembunyi atau secara gelap. Sedangkan penyelundupan diartikan pemasukan barang secara gelap untuk menghindari bea masuk atau karena menyelundupkan barang-barang terlarang. ${ }^{5}$

Tindak Pidana Penyelundupan (smuggling atau Smokkle) merupakan kegiatan mengimpor, mengekspor, mengantar barang dengan tidak memenuhi peraturan perundang-undangan yang berlaku, atau tidak memenuhi formalitas pabean yang ditetapkan oleh undang-undang. ${ }^{6}$ Tindak pidana ini jelas merugikan negara, karena negara kehilangan pendapatan yang seharusnya di setorkan dalam kas negara. Hal tersebut terjadi, karena barang impor yang masuk ke Indonesia tidak dikenakan pajak karena diselundupkan atau secara ilegal. ${ }^{7}$ Secara geografis, posisi Indonesia sangat strategis. Indonesia memiliki garis pantai yang luas, hamparan pulau-pulau yang sering dijadikan sebagai jalur tikus bagi para penyelundup untuk menyelundupkan barang-barang ilegal ke Indonesia. Kurangnya tenaga ahli dan pengawasan dalam mengantisispasi tindak pidana penyelundupan dan lambatnya lembaga penegak hukum menjadi faktor sering terjadinya kasus penyelundupan.

${ }^{2}$ Bea cukai bekasi (2017). Tentang Tupoksi di akses pada tanggal 09 Juni 2017 pukul 21.34 WIB http://bcbekasi.beacukai.go.id/Tentang/tupoksi.html

${ }^{3}$ Pratama, Rico Nandra. (2018). Peranan Penyidik Pegawai Negeri Sipil Bea Cukai Dalam Pencegahan Tindak Pidana Penyelundupan Rokok Via Tol Laut. Fakultas Hukum Universitas Lampung Bandar Lampung. 11(4) .

${ }^{4}$ Yusuf, Iswandi H. (2016). Peran Kejaksaan Dalam Menanggulangi Tindak Pidana Penyelundupan, Universitas Sam Ratulangi, 4(3).

${ }^{5}$ Leden Marpaung. (2016). Pemberantasan dan Pencegahan Tindak Pidana Ekonomi. Jakarta: Sinar Grafika. h. 3

${ }^{6}$ Chibro, Soufnir. (1992). Pengaruh Tindak Pidana Penyelundupan Terhadap Pembangunan. Jakarta: Sinar Grafika. h. 5.

${ }^{7}$ Sukinto, Yudi Wibowo. (2013). Tindak Pidana Penyelundupan di Indonesia, Kebijakan Formulasi Sanksi Pidana. Jakarta: Sinar Grafika. h. 47. 
Penyelundupan di Indonesia bukanlah hal baru terutama di kalangan masyarakat terlebih yang membutuhkan smartphone canggih dengan harga yang relatif murah. Smartphone selundupan ini menjadi alternatif yang sesuai dengan budget masyarakat agar tetap memiliki barang yang mereka inginkan sekalipun ilegal. Seperti yang kita ketahui harga smartphone lewat jalur resmi yang diperjualbelikan harganya lebih mahal dari pada harga smartphone yang lewat jalur selundupan, sehingga ketidaksanggupan masyarakat dengan harga yang mahal penyebab smartphone illegal dijadikan pilihan masyarakat untuk memiliki smartphone yang mereka inginkan.

Kasus penyelundupan yang terjadi di tangani oleh Bea Cukai Jakarta. Luasnya daerah kepabeanan Indonesia menjadikan pengawasan yang dilakukan belum maksimal sehingga masih banyak barang yang dapat keluar masuk secara ilegal tanpa membayar bea cukai. Sehingga di perlukan kerja sama masyarakat dalam mengurangi permasalahan atas penyelundupan yang terjadi di kepabeanan Indonesia. Berdasarkan permasalahan diatas, tulisan ini akan menjelaskan upaya penanggulangan yang dapat dilakukan oleh Bea dan Cukai Jakarta terhadap penyelundupan smarthphone.

\section{Metode Penelitian}

Penelitian dilakukan secara yuridis empiris dengan menggunakan pendekatan undang-undang, pendekatan kasus, dan pendekatan historis. Data yang digunakan adalah data primer yang berasal dari fakta di lapangan yang diperoleh dengan cara wawancara dengan narasumber. Kemudian data sekunder yang diperoleh dari aturan perundang-undangan dan studi keperpustaan meliputi bahan hukum primer, bahan hukum sekunder dan bahan hukum tersier. Data sekunder adalah data yang diperoleh dari hasil penelaahan kepustakaan atau penelaahan terhadap berbagai literatur atau bahan pustaka yang berkaitan dengan masalah atau materi penelitian yang sering disebut sebagai bahan penelitian. ${ }^{8}$ Data primer dan data sekunder yang diperoleh dalam penelitian ini akan disusun secara sistematis dan dianalisis. Analisis dilakukan secara deskriptif, kualititatif, yaitu dengan memberikan pemaparan dan menjelaskan secara rinci dan mendalam untuk mengungakap apa peristiwa yang terjadi dan mencari maksud nilai-nilai yang terkandung di dalamnya. ${ }^{9}$

\section{Hasil dan Pembahasan}

\section{A. Gambaran Umum Penyelundupan Smartphone Ilegal}

Direktorat Jenderal Bea Dan Cukai Jakarta memiliki beberapa kantor pengawasan dari sektor udara, darat maupun laut. Pengawasan yang sudah ada di setiap sektor jalur masuknya perdagangan ekspor dan impor tidak menurunkan kejahatan penyelundupan yang masih banyak dilakukan. Tabel di bawah ini menggambarkan penyelundupan smartphone yang terjadi di beberapa daerah di Indonesia.

Tabel I

Data Hasil Penyelundupan Khusus Smartphone Indonesia

\begin{tabular}{clc}
\hline Tahun & \multicolumn{1}{c}{ Daerah } & \multicolumn{1}{c}{ Jumlah } \\
\hline 2014 & Jakarta, bandara soekarno hatta & 3 \\
2015 & Jakarta, bandara soekarno hatta & 1 \\
2016 & Kalimantan barat, kanwil Kalimantan bagian barat & 3 \\
& 1. Jakarta, bandara soekarno hatta & 1 \\
\multirow{2}{*}{2017} & 2. Aceh & 2 \\
& 3. kepri (kepulauan riau) & 3.4 \\
2018 & Jakarta, kanwil Jakarta & 2 \\
\hline
\end{tabular}

Sumber : Direktorat Jenderal Bea dan Cukai 2014-2018

\footnotetext{
8 ND, Mukti Fajar dan Achmad, Yulianto. (2015). Dualisme Penelitian Hukum Normatif \& Empiris. Yogyakarta: Pustaka Pelajar. Ibid, h. 156

${ }^{9}$ Ibid, h. 283
} 
Berdasarkan hasil wawancara dengan Bapak Elang selaku Subdirektorat Penyidik Bea Dan Cukai jumlah smartphone ilegal yang beredar di Indonesia sebanyak 20\% dari smartphone yang ada. Adapun modus penyelundupan smartphone ilegal dilakukan oleh importir yang tidak berkedudukan di Indonesia namun menjalin kerjasama dengan beberapa oknum atau distributor. Selain itu pendistribusian smartphone ilegal juga melibatkan supir yang berfungsi sebagai kurir. Dari serangkaian penyidikan yang dilakukan, diketahui bahwa kurir tidak mengetahui sama sekali dan tidak boleh melihat isi paket atau barang apa yang mereka bawa, kurir hanya bertugas mengirimkan barang sesuai dengan alamat yang tertera dengan upah yang lebih tinggi dari pengiriman biasa. Dari hasil wawancara diatas penulis berkesimpulan faktor yang menyebabkan penyelundupan smartphone illegal terjadi di Indonesia antara lain, masih lemahnya pengawasan, kurangnya informasi, dan kurangnya kerjasama dalam instansi penegak hukum yang mengakibatkan lambatnya penanganan dan penyelesaian terhadap penyelundupan yang terjadi.

Adapun faktor-faktor yang menyebabkan maraknya terjadi penyelundupan smartphone ilegal, sebagai berikut :

a. Faktor Geografis

Luasnya daerah kepabeanan Indonesia menjadi kendala dalam penanganan kasus penyeludupan. Indonesia memiliki banyak pulau-pulau kecil yang menjadi jalur penyelundupan dikarenakan minimnya pengawasan dan banyaknya jalur-jalur tikus menjadikan penyelundupan tempat terjadinya transaksi penyelundupan.

b. Faktor Penegak Hukum

Kurangnya tenaga ahli dan kurangnya anggota dalam mengawasi setiap daerah perbatasan menjadikan faktor lambatnya penanganan. Diperlukan pelatihan atau pendidikan khusus untuk tenaga ahli sebelum di tempatkan secara langsung ke daerah perbatasan.

c. Faktor Ekonomi

Faktor ekonomi menjadi faktor utama dalam tindak pidana penyelundupan. Keuntungan yang diperoleh dalam penyelundupan smartphone ilegal sangat besar, keuntungan tersebut diperoleh karena smartphone yang diperjualbelikan secara ilegal tidak perlu membayar pajak. Semua orang yang terlibat dalam penyelundupan tersebut mendapatkan keuntungan, baik sebagai penyedia jasa, kurir, pedagang dan masyarakat.

\section{B. Penanggulangan Tindak Pidana Penyelundupan Dalam Unit Direktorat Jenderal Bea dan} Cukai

Upaya penanggulangan dapat di lihat dari tugas masing-masing subdirektoat berdasarkan Peraturan Direktur Jenderal Bea Dan Cukai Nomor P-53/Bc/2010 Tentang Tatalaksana Pengawasan Direktur Jenderal Bea Dan Cukai, Susunan tatalaksana pengawasan Direktorat Jenderal Bea Dan Cukai, yang dijelaskan sebagai berikut :

\section{a. Intelejen}

Intelejen merupakan pengelolaan informasi meliputi pengumpulan, penilaian, analisis, distribusi dan evaluasi data atau informasi, yang dilaksanakan oleh Unit Intelijen. Kegiatan intelijen ini dilaksanakan oleh Unit Intelijen dalam rangka pendeteksian dini atas pelanggaran dalam Pengumpulan Data atau Informasi.

1) Internal DJBC berupa data atau informasi yang diperoleh melalui kegiatan sebagai berikut:

a) Surveillance dilaksanakan dengan kegiatan pengamatan terhadap orang, tempat, sarana pengangkut dan/atau obyek tertentu secara berkesinambungan pada periode tertentu yang dilakukan secara tertutup dalam rangka pengumpulan atau pendalaman data atau informasi yang dapat menunjukkan adanya indikasi pelanggaran kepabeanan dan/atau cukai.

b) Monitoring dilaksanakan dengan kegiatan pengamatan terhadap data-data transaksi pelayanan dan pengawasan kepabeanan dan/atau cukai.

2) Eksternal DJBC berupa data atau informasi yang diperoleh dari laporan masyarakat atau institusi atau sumber eksternal lainnya yang bersifat kegiatan lapangan dilakukan dengan surat tugas dan dibuat laporan. 
Hasil dari Penilaian dilakukan dengan pengklasifikasian data atau informasi berdasarkan lembaga informasi dalam rangka menentukan kelayakan data atau informasi untuk dilakukan analisis. Lembar Kerja Analisis Intelijen (LKAI) ditindaklanjuti dengan penerbitan produk intelijen berupa dalam berupa :

1) Nota Hasil Intelijen ( $\mathrm{NHI}$ ) yang memuat informasi mengenai indikasi kuat adanya pelanggaran kepabeanan dan/atau cukai yang bersifat spesifik dan mendesak dari Unit Intelijen, untuk segera dilakukan penindakan oleh Unit Penindakan Kantor Pelayanan;

2) Nota Informasi Penindakan (NIP) yang memuat informasi mengenai indikasi adanya pelanggaran kepabeanan dan/atau cukai yang bersifat spesifik dari Unit Intelijen, untuk dapat dilakukan penindakan oleh Unit Penindakan Kantor Pusat atau Kantor Wilayah secara horizontal;

3) Informasi (NI) yang memuat informasi mengenai indikasi adanya pelanggaran kepabeanan dan/atau cukai yang bersifat umum atau spesifik untuk dapat dilakukan penelitian mendalam oleh Unit Intelijen di Kantor Wilayah atau Kantor Pelayanan.

\section{b. Penindakan}

Kegiatan penindakan dilaksanakan oleh unit penindakan untuk mengamankan hak-hak negara dan menjamin pemenuhan kewajiban pabean dan/atau cukai dengan upaya fisik yang bersifat administratif sesuai ketentuan yang berlaku. Penindakan dilaksanakan berdasarkan informasi tentang indikasi pelanggaran yang diperoleh dari unit intelijen. Informasi yang diperoleh dari unit intelijen berupa Nota Hasil Intelijen (NHI), Nota Informasi Penindakan (NIP), atau informasi lainnya. Tindakan yang dilakukan oleh subdirektorat penindakan sebagai berikut:

1) Penghentian

Penghentian sarana pengangkut serta barang impor, ekspor, barang tertentu, barang kena cukai dan/atau barang lain yang terkait yang berada di atasnya, dilaksanakan oleh Pejabat secara selektif berdasarkan informasi adanya dugaan pelanggaran. Sarana pengangkut meliputi:

a) Alat yang digunakan untuk mengangkut impor, ekspor, barang tertentu, barang kena cukai dan/atau barang lainnya yang terkait di darat, di air, atau di udara; dan

b) Orang pribadi yang mengangkut impor, ekspor, barang tertentu, barang kena cukai dan/atau barang lainnya tanpa menggunakan alat angkut.

2) Pemeriksaan

Pemeriksaan Sarana Pengangkut, Barang, Bangunan/tempat dan/atau Badan Pemeriksaan dilakukan terhadap sarana pengangkut, barang, tempat/bangunan atau orang pribadi yang diduga terkait pelanggaran. Pemeriksaan sarana pengangkut dilaksanakan :

a) Terhadap sarana pengangkut laut/darat pada saat pengangkutan;

b) Terhadap sarana pengangkut laut/udara pada saat kedatangan atau keberangkatan dipelabuhan laut/udara.

Pemeriksaan dilaksanakan dengan memeriksa dokumen, sarana pengangkut dan fisik barang. Pemeriksaan barang dilaksanakan terhadap barang impor atau ekspor di dalam/luar kawasan pabean atau di perbatasan darat dengan memeriksa fisik barang secara keseluruhan berdasarkan dokumen pabean atau dokumen barang lainnya meliputi :

a) Jumlah dan jenis kemasan dan/atau barang;

b) Merek/ tipe barang;

c) Negara asal barang; dan/atau

d) Spesifikasi lainnya.

Pemeriksaan orang pribadi dilakukan terhadap orang pribadi yang :

a) Berada di atas atau baru saja turun dari sarana pengangkut yang masuk ke dalam daerah pabean

b) Berada di atas atau siap naik ke sarana pengangkut dengan tujuan keluar daerah pabean. 
c) Sedang berada di atau baru saja meninggalkan Tempat Penimbunan Sementara atau Tempat Penimbunan Berikat, atau

d) Sedang berada di atau baru saja meninggalkan kawasan pabean

3) Pencegahan

Pencegahan dilaksanakan terhadap sarana pengangkut dan/atau barang yang diduga terkait dengan pelanggaran. Pencegahan terhadap sarana pengangkut laut/udara, dilaksanakan dengan mencegah keberangkatan atau mencegah untuk melanjutkan perjalanan sarana pengangkut yang memuat barang impor atau ekspor yang :

a) Terdapat perbedaan jumlah dan/atau jenis kemasan/barang dengan manifest;

b) Terdapat manifest lebih dari satu yang memuat data berbeda, atau tidak dapat menunjukkan manifest; atau

c) Terdapat barang yang dicantumkan dalam manifest tetapi terdapat dugaan melanggar ketentuan larangan dan pembatasan di bidang impor, ekspor, barang tertentu atau cukai.

Pencegahan terhadap sarana pengangkut darat, dilaksanakan dengan mencegah keberangkatan atau mencegah untuk melanjutkan perjalanan sarana pengangkut yang memuat barang impor, ekspor, barang tertentu atau barang kena cukai, yang sebagian atau seluruhnya tidak memenuhi kewajiban kepabeanan dan/atau cukai. Pencegahan terhadap barang, dilakukan dengan menunda pengeluaran, pemuatan, pembongkaran dan pengangkutan barang impor, ekspor, barang tertentu atau barang kena cukai, yang sebagian atau seluruhnya tidak memenuhi kewajiban kepabeanan dan/atau cukai.

4) Penyegelan

Penyegelan dilaksanakan dengan mengunci, menyegel dan/atau melekatkan tanda pengaman yang diperlukan terhadap sarana pengangkut, barang, bangunan atau tempat yang diduga terkait pelanggaran. Penyegelan dilaksanakan dengan menggunakan segel atau tanda pengaman yang terbuat dari kertas, plastik, logam, lak dan/atau bahan lainnya dengan bentuk tertentu berupa lembaran, pita, kunci, kancing dan/atau bentuk lainnya yang dilengkapi dengan piranti elektronik atau tidak. Penyegelan dilakukan dalam rangka :

a) Penindakan, penyidikan, audit, penyitaan dalam rangka penagihan pajak dengan surat paksa; atau

b) Pengamanan terhadap barang yang belum diselesaikan kewajiban pabean dan/atau cukainya atau barang lain yang harus diawasi.

\section{c. Penyidik}

Kegiatan penanganan perkara dilaksanakan oleh Unit Penyidikan untuk menentukan ada tidaknya pelanggaran dan/atau membuat terang pelanggaran. Penanganan perkara meliputi kegiatan penelitian/penyelidikan dan penyidikan.

Pelaksanaan penelitian meliputi kegiatan:

1) Penerimaan Laporan Pelanggaran (LP) dari unit penindakan atau dari instansi lain

2) Pemanggilan/ permintaan keterangan saksi dan/atau pelaku yang terkait dengan dugaan pelanggaran

3) Pengumpulan dan penelitian surat-surat/dokumen-dokumen yang terkait dengan dugaan pelanggaran.

4) Pencacahan dan pemeriksaan Barang hasil Penindakan meliputi jumlah, jenis, merk, type, dan spesifikasi lainnya.

5) Penelitian dan analisis terhadap pelanggaran

6) Pelaksanaan gelar perkara untuk memperoleh pendapat secara lebih komprehensif.

7) Pengajuan permintaan audit investigasi dalam rangka mendukung proses penelitian/penyelidikan dalam hal diperlukan.

8) Pembuatan resume penelitian dengan kesimpulan

9) Penyampaian usulan alternatif penyelesaian perkara

Dalam pelaksanaan penelitian dan penyidikan dapat diadakan gelar perkara dengan maksud dan tujuan untuk memperoleh masukan guna penyelarasan atau penyempurnaan dalam pemberkasan dan untuk menyampaikan informasi/laporan guna pemantauan perkembangan penelitian/penyidikan serta pengelolaan proses penanganan perkara. 
d. Pengawasan Didaerah Perbatasan Dan Pulau-Pulau Kecil Oleh Direkorat Jenderal Bea Dan Cukai

Tindak lanjut mengenai penegakan atas daerah perbatasan Indonesia berdasarkan peraturan P-53/BC/2010 Tentang Tatalaksana Pengawasan Direktur Jenderal Bea Dan Cukai meliputi :

1) Patroli Laut

Patroli laut dilaksanakan secara rutin atau sewaktu-waktu dalam rangka pencegahan pelanggaran kepabeanan dan/atau cukai termasuk untuk mencari dan menemukan dugaan pelanggaran kepabeanan dan/atau cukai. Patroli Laut dilaksanakan di seluruh wilayah perairan Indonesia serta tempat-tempat tertentu di Zona Ekonomi Eksklusif dan landas kontinen sebagaimana dimaksud dalam undang-undang.

2) Patroli Darat

Patroli darat dilaksanakan secara rutin atau sewaktu-waktu dalam rangka pencegahan pelanggaran termasuk untuk mencari dan menemukan dugaan pelanggaran. Patroli darat dilaksanakan di dalam daerah pabean, meliputi:
a) Pelabuhan laut/udara;
b) Kawasan pabean;
c) Tempat lain dalam daerah pabean;
d) Perbatasan darat;
e) Pabrik, tempat penyimpanan, tempat usaha penyalur atau tempat penjualan eceran barang kena cukai;
f) Peredaran bebas barang kena cukai.

Dalam melakukan pengawasan Direktorat Jenderal Bea Cukai bekerjasama dengan penegak hukum lainnya sebagaimana yang dijelaskan dalam undang-undang kepabeanan Pasal 76 ayat (1) yang berbunyi : "Dalam melaksanakan tugas berdasarkan Undang-Undang ini pejabat bea dan cukai dapat meminta bantuan Kepolisian Republik Indonesia, Tentara Nasional Indonesia, dan/atau instansi lainnya".

e. Alat Bantu Yang Digunakan Oleh Direktorat Jenderal Bea Dan Cukai Penggunaan alat bantu sangat di perlukan dalam melakukan pengawasan terhadap barang yang masuk maupun keluar dari wilayah Indonesia baik di pelabuhan maupun di bandara. Adapun alat bantu tersebut, sebagai berikut

Tabel II

Alat Canggih Dimiliki Direktorat Bea Dan Cukai

\begin{tabular}{cccc}
\hline No & Sarana operasi & Lokasi & Alat \\
\hline $\mathbf{1}$ & Patroli laut & Laut & Senjata api \\
Kapal \\
$\mathbf{2}$ & Patroli darat & Bandara & X-Ray Scanner \\
& Pelabuhan & Gamma Ray \\
\hline
\end{tabular}

\section{f. Tindakan Atas Barang Rampasan (Smartphone) Oleh Direktorat Jenderal Bea Dan} Cukai

Keberadaan smartphone illegal sangat merugikan Negara sehingga perlu di lakukan pengawasan di setiap kepabeanan Indonesia. Terhadap barang rampasan di lakukan pemusnahan jika barang yang sudah di selidiki dan sudah di tetapkan pelakunya, sekalipun jumlah barang hasil rampasan tersebut yang harus di musnahkan sangat besar. Hal tersebut perlu dilakukan selain barang rampasan tidak menguntungkan bagi Negara, sinyal atau frekuensi dari yang dipancarkan oleh smartphone illegal akan mengganggu keamanan yang ada di Indonesia. ${ }^{10}$

Dari kesimpulan diatas barang hasil rampasan atas penyelundupan smartphone illegal dan barang rampasan lainnya di kota Jakarta dilakukan dengan cara sebagai berikut :

${ }^{10}$ Ibid, 
1) Pemusnahan : Pemusnahan dilakukan barang hasil penindakan merupakan barang yang mudah busuk, merusak, berbahaya dan/atau memerlukan biaya penyimpanan yang tinggi.

2) Pelelangan : Pelelangan dilakukan terhadap barang hasil penindakan dapat dilakukan, dalam hal pada tahap penyidikan, atas barang yang mudah rusak, berbahaya dan/atau memerlukan biaya penyimpanan yang tinggi.

3) Hibah : Barang hasil penindakan dapat dilakukan penghibahan dalam hal barang tersebut dinilai memiliki kegunaan/manfaat bagi institusi atau masyarakat yang membutuhkan.

Pemusnahan dilakukan apabila barang tersebut mudah busuk, rusak dan berbahaya seperti halnya dengan smarphone illegal diindikasikan bahwa membahayakan frekuensi keamanan Negara sehingga barang tersebut akan dimusnahkan sedangkan dilelang dilakukan bila perawatannya yang tinggi sehingga akan dilakukan pelelangan yang dimana hasil pelelangan akan masuk kas Negara contoh dari mobil mewah.

g. Sanksi Hukum Petugas Direktorat Jenderal Bea Dan Cukai Ikut Terlibat Dalam Melawan Hukum.

Penyelundupan smartphone ilegal tidak jarang melibatkan aparat yang memiliki kewenangan dalam Direktorat Jenderal Bea dan Cukai atau aparatur sipil negara lainnya. Dalam ketentuan Pasal 7 Peraturan Pemerintah Republik Indonesia Nomor 53 Tahun 2010 Tentang Disiplin Pegawai Negeri Sipil ada 3 jenis hukuman yang dapat dijatuhkan, yaitu :11

1) Jenis hukuman disiplin ringan terdiri dari:

a) Teguran lisan;

b) Teguran tertulis; dan

c) Pernyataan tidak puas secara tertulis.

2) Jenis hukuman disiplin terdiri dari:

a) Penundaan kenaikan gaji berkala selama 1 (satu) tahun;

b) Penundaan kenaikan pangkat selama 1 (satu) tahun; dan

c) Penurunan pangkat setingkat lebih rendah selama 1 (satu) tahun.

3) Jenis hukuman disiplin berat terdiri dari:

a) Penurunan pangkat setingkat lebih rendah selama 3 (tiga) tahun;

b) Pemindahan dalam rangka penurunan jabatan setingkat lebih rendah;

c) Pembebasan dari jabatan;

d) Pemberhentian dengan hormat tidak atas permintaan sendiri sebagai PNS; dan

e) Pemberhentian tidak dengan hormat sebagai PNS.

Dalam Pasal 102 C Undang-Undang Republik Indonesia Nomor 17 Tahun 2006 Tentang Perubahan Atas Undang-Undang Nomor 10 Tahun 1995 Tentang Kepabeanan. Di jelaskan bahwa perbuatan tindak pidana sebagaimana diatur dalam Pasal 102, Pasal 102A, Pasal 102B dilakukan oleh pejabat dan aparat penegak hukum, pidana yang dijatuhkan dengan pidana sebagaimana ancaman pidana dalam Undang-Undang ini ditambah 1/3 (satu pertiga).

Dapat disimpulkan setiap anggota direktorat bea dan cukai yang terbukti ikut andil dalam penyelundupan akan mendapat hukuman yang sama seperti PNS di mana akan ada 3 (tiga) peringatan dalam hukumnan yang pertama hukuman ringan dapat berupa teguran, kedua hukuman ringan berupa penundaan gaji 1 (satu) bulan - 1 (satu) tahun, dan ketiga hukuman berat penurunan pangkat hingga pemecatan tetapi ada hukuman pidana yang akan menjerat penegak hukum direktorat bea dan cukai akan dikenakan ancaman hukum pidana ditambah dengan $1 / 3$ (satu pertiga) nya.

\section{Simpulan}

Faktor-faktor yang menyebabkan maraknya terjadi penyelundupan smartphone ilegal, seperti faktor geografis, faktor penegak hukum dan faktor ekonomi. Dalam upaya penanggulangan penyelundupan smartphone yang terjadi di Jakarta, Bea dan Cukai Jakarta telah melaksanakan aturan

${ }^{11} \mathrm{Ibid}$ 
penegakan hukum yang sesuai dengan Peraturan Direktorat Jenderal Bea Dan Cukai Nomor P53/Bc/2010 Tentang Tatalaksana Pengawasan Direktorat Jenderal Bea Dan Cukai. Peraturan ini mengatur tentang tatalaksana pengawasan Direktorat Jenderal Bea dan Cukai yang terdiri dari beberapa subdirektorat seperti subdirektorat Intelejen yang bertugas mengelola informasi. Subdirektorat penindakan yang bertugas melakukan penghentian, pemeriksaan, pencegahan, dan penyegelan. Subdirektorat Penyidik menentukan ada tidaknya pelanggaran dan/atau membuat terang pelanggaran. Subdirektorat Pengawasan meliputi patroli laut dan patroli darat. Alat bantu yang digunakan meliputi Senjata api, Kapal, X-Ray Scanner, dan Gamma Ray. Adapun tindakan terhadap barang rampasan dilakukan dengan pemusnahan, pelelangan, dan hibah. Sanksi yang dapat dijatuhkan kepada aparatur sipil negara yang terlibat dalam penyelundupan antara dibedakan menjadi hukuman disiplin ringan dan hukuman disiplin berat.

\section{Daftar Pustaka.}

\section{Buku}

Chibro, S. (1992). Pengaruh Tindak Pidana Penyelundupan Terhadap Pembangunan. Jakarta: Sinar Grafika

Fajar ND, M dan Achmad, Y. (2013). Dualisme Penelitian Hukum Normatif \& Empiris. Yogyakarta : Pustaka Pelajar

Marzuki, P.M. (2005). Penelitian Hukum. Jakarta: Prenadamedia Group

Sukinto, Y.W. (2013). Tindak Pidana Penyelundupan di Indonesia, Kebijakan Formulasi Sanksi Pidana. Jakarta: Sinar Grafika

\section{Jurnal}

Haeryndra, M. F. (2014). Kajian Yuridis Kriteria Tentang “Personil Pengendali Korporasi” Terkait Pertanggungjawaban Pidana Korporasi Berdasarkan Pasal 6 Ayat (1) Undang-Undang Republik Indonesia Nomor 8 Tahun 2010 Tentang Pencegahan Dan Pemberantasan Tindak Pidana Pencucian Uang. Jurnal Mahasiswa Universitas Brawijaya Fakultas Hukum Malang, 9(2).

Pratama, R.N. (2018). Peranan Penyidik Pegawai Negeri Sipil Bea Cukai Dalam Pencegahan Tindak Pidana Penyelundupan Rokok Via Tol Laut. Fakultas Hukum Universitas Lampung Bandar Lampung, 11(4).

Yusuf, I.H. (2016). Peran Kejaksaan Dalam Menanggulangi Tindak Pidana Penyelundupan. Universitas Sam Ratulangi, 4(3).

\section{Regulasi}

Undang-Undang Dasar Republik Indonesia Tahun 1945

Undang-Undang Nomor 17 Tahun 2006 Tentang Perubahan atas Undang-Undang Nomor 10 Tahun 1995 tentang Kepabeanan

Undang-Undang Nomor 39 Tahun 2007 tentang Perubahan atas Undang-Undang Nomor 11 Tahun 1995 tentang Cukai.

Peraturan Direktur Jenderal Bea Dan Cukai Nomor P-53/BC/2010 Tentang Tatalaksana Pengawasan Direktur Jenderal Bea Dan Cukai

\section{Website}

Bea Cukai Bekasi. (2017). Tentang Tupoksi. di akses pada tanggal 09 Juni 2017 http://bcbekasi.beacukai.go.id/Tentang/tupoksi.html

Rotasi. (2013). Ponsel Pintar Gaya Hidup, di akses pada tanggal 21 April 2018, http://rotasinews.com/ponsel-pintar-jadi-gaya-hidup/

\section{Wawancara}

Elang Anggota Subdirektotat Penyidik Direktorat Jenderal Bea dan Cukai, Jakarta

Putu Kepala Unit Direktotat Reserse Kriminal Khusus, Polda Metro Jaya, Jakarta 